\title{
NOTE
}

\section{Phototrophic and heterotrophic pico- and nanoplankton in anoxic depths of the central Baltic Sea}

\author{
Andrea E. Detmer, Hanna C. Giesenhagen, Verena M. Trenkel, \\ Herbert Auf dem Venne, Frank J. Jochem
}

Institut für Meereskunde, Düsternbrooker Weg 20, D-24105 Kiel, Germany

\begin{abstract}
An unexpected increase of phototrophic and heterotrophic pico- and nanoplankton under anoxic conditions was encountered in the central Baltic Sea below $120 \mathrm{~m}$ depth in August 1991 and 135 m depth in July 1992, respectively. Cell abundances in anoxic layers were up to 10 times higher for chroococcoid cyanobacteria, 6 to 8 times for phototrophic nanoflagellates and 3 to 4 times for bacteria, as compared to the overlaying aphotic oxic layers. A characteristic ciliate community occurred at the oxic/anoxic interface. Phototrophic organisms of anoxic depths were capable of productivity when reoxygenated and returned into the light. Considerable grazing on bacteria $\left(0.41\right.$ to $\left.0.65 \mathrm{~d}^{-1}\right)$ and chroococcoid cyanobacteria ( 1.19 to $1.29 \mathrm{~d}^{-1}$ ) was revealed by serial dilution experiments. Cyanobacteria showed gross growth rates of 0.85 to $1.33 \mathrm{~d}^{-1}$ under aphotic/anoxic conditions. The origin of deep-water phototrophic pico- and nanoplankton and the existence of a permanent anaerobic microbial food web are discussed.
\end{abstract}

A number of investigations have emphasized the occurrence of procaryotic and eucaryotic pico- and nanoplankton in the oxic deep-sea (Hamilton et al. 1968, Fournier 1970,1971, Silver \& Alldredge 1981, Platt et al. 1983, Davis et al. 1985, Silver et al. 1986, Lochte \& Turley 1988). Little information exists, however, on pico- and nanoplankton in anoxic depths. For nearshore areas, recent investigations revealed distinct populations at the oxic/anoxic interface and in anoxic near-bottom layers (Fenchel et al. 1990). Anoxic conditions are typical for the deep basins of the Baltic Sea (Matthäus 1986). The present paper describes our observations of the occurrence of phototrophic and heterotrophic pico- and nanoplankton in deep anoxic water layers of the Gotland Basin, central Baltic Sea. We dis- cuss whether these unique biotas are of overall significance for the interpretation of the Baltic ecosystem.

Material and methods. Data presented were collected during RV 'Alkor' cruises BAMBI '91 and BAMBI ' 92 (Baltic Microbial Biology Investigation) in August 1991 (8 d drift study) and July 1992 (9 d drift study) in the eastern part of the Gotland Sea, central Baltic (Fig. 1).

Water samples from the surface to the bottom were taken with black PVC Niskin-type water bottles each morning. Temperature was recorded by a ME CTD probe and salinity was derived from salinometry of water cast samples. In 1992, in situ fluorescence and turbidity were recorded by a Backscatt fluorescence sensor mounted on the CTD probe. Oxygen concentrations were estimated by Winkler titration and $\mathrm{H}_{2} \mathrm{~S}$ concentrations as described by Grasshoff et al. (1983).

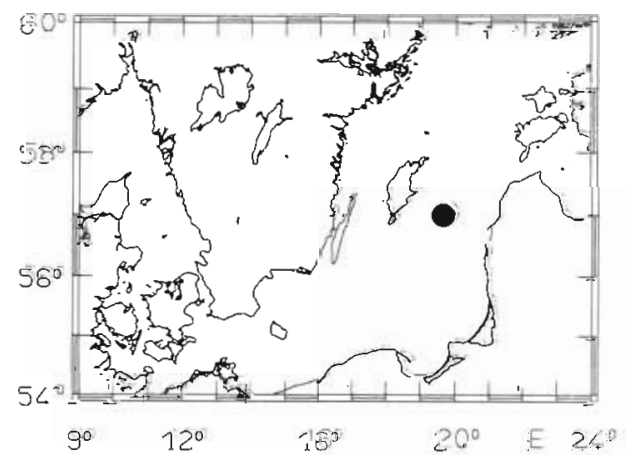

Fig 1. Location of drift studies during BAMBI '91 and BAMBI ' 92 in the central Baltic Sea at $57^{\circ} 30^{\prime} \mathrm{N}, 20^{\circ} 19^{\prime} \mathrm{E}$ 
Abundances of pico- and nanoplankton were determined by epifluorescence and light microscopy. For epifluorescence microscopy, samples were fixed with glutaraldehyde (final concentration $0.3 \%$ ) and aliquots filtered onto Irgalan Black prestained Nuclepore fiiters of $0.2 \mu \mathrm{m}$ pore size. Unstained chroococcoid cyanobacteria (Syn) and phototrophic flagellates (ANF) could easily be distinguished by their different autofluorescence, orange and red respectively, under blue-light excitation (450 to $490 \mathrm{~nm}$ ). For bacteria, Acridineorange staining (Zimmermann 1977, Porter \& Feig 1980; $0.015 \%$ solution) and for heterotrophic flagellates (HNF), Proflavine staining (Haas 1982) were applied. Filters were prepared within $6 \mathrm{~h}$ after sampling and stored frozen $\left(-18^{\circ} \mathrm{C}\right)$. In order to prevent cell loss, stained preparates were counted within $3 \mathrm{wk}$ (Turley \& Hughes 1992). For phototrophic organisms and bacteria, about 200 cells were counted in a minimum of 20 fieids, counting error thus being below $15 \%$ (Venrick 1978). In the case of heterotrophic nanoflagellates, 30 to 100 cells were counted within 70 to 220 fields (counting error: 20 to $35 \%$ ). For the quantitative analysis of the abundance of ciliate species, samples were fixed in $5 \%$ by volume Bouin's fixative and stained by the quantitative protargol method (Montagnes \& Lynn 1987); 10 to 200 cells were counted.

To assess the physiological state of phototrophic picoand nanoplankton in terms of productivity potential, the uptake of $\mathrm{H}^{14} \mathrm{CO}_{3}$ (Steeman Nielsen 1952) was measured in samples from anoxic depths $(160 \mathrm{~m}$ on BAMBI ' $91,170 \mathrm{~m}$ on BAMBI '92). Triplicate samples were incubated for $8 \mathrm{~h}$ in a deck incubator cooled by running surface seawater $\left(18\right.$ to $20^{\circ} \mathrm{C}$ ) under anoxic as well as oxygenated conditions achieved by 20 min airbubbling prior to ${ }^{14} \mathrm{C}$ addition. Samples from $5 \mathrm{~m}$ depth or the surface were taken as references. After incubation, all samples were size-fractionated by filtering through $2.0 \mu \mathrm{m}$ Nuclepore filters onto $0.2 \mu \mathrm{m}$ membrane filters and measured in a Packard TriCarb liquid scintillation counter. Primary production of picoplankton was normalized to cellular production using cell numbers derived from epifluorescence microscopy. Measurements of $\mathrm{CO}_{2}$-dark fixation in the water column were performed during BAMBI ' 91 . To follow the dark uptake of $\mathrm{H}^{14} \mathrm{CO}_{3}, 100 \mathrm{ml}$ samples in duplicate and a formalin-killed sample which served as a blank were amended with $10 \mu \mathrm{Ci} \mathrm{NaH}{ }^{14} \mathrm{CO}_{3}$ and incubated at in situ temperature for $10 \mathrm{~h}$. Contamination with air was avoided for samples from the oxic/anoxic interface.

To estimate the grazing impact on chroococcoid cyanobacteria and bacteria under oxic and anoxic conditions, serial dilution experiments (Landry \& Hassett 1982) were conducted. Sample portions were 100,75 , 50,33 and $20 \%$. In both years, samples were incubated for $24 \mathrm{~h}$ at in situ temperatures.
In 1991, samples were taken from $2 \mathrm{~m}$ and $160 \mathrm{~m}$ depth, prefiltered through a $100 \mu \mathrm{m}$ net and incubated; no precautions were taken to avoid oxygen- and lightcontamination during tapping in the case of the deepwater samples, which were incubated in the dark. Surface experiments were repeated 4 times with triplicate samples per dilution step, the deep experiment was performed once with duplicate samples. In 1992, 1 serial dilution experiment was performed under strictly anoxic conditions. Incubation bottles $(100 \mathrm{ml})$ were sealed with silicon stoppers and flushed with nitrogen gas for $1 \mathrm{~min}$. Prefiltered $(0.2 \mu \mathrm{m})$ water from $170 \mathrm{~m}$ depth, dedicated for dilutions, was kept anoxic by addition of $\mathrm{NaS}$ as reductor and bubbling with nitrogen gas. Anoxia was monitored by addition of resazurine as oxygen indicator (colourless in the absence of oxygen; Süßmuth et al. 1987). Samples from $170 \mathrm{~m}$ depth were taken from water bottles by nitrogen-flushed glass syringes and injected into the anoxic dilution water through silicon stoppers, avoiding any contact with air. Cell numbers were estimated by epifluorescence microscopy before and after incubation.

Apparent growth rates (ln $N_{t} / N_{0}$ ) were plotted versus dilution steps (not shown) and growth rates $(\mu)$ and grazing rates $(g)$ were estimated by linear regression (Landry \& Hasset 1982). The percentage of gross production grazed $\left(\% P_{\mathrm{g}}\right)$ was calculated using the following equations:

Gross production $P_{\mathrm{g}}=\mu \times B^{*}$;

Mean biomass $\quad B^{*}=\left(B_{t}-B_{0}\right) / \ln \left(B_{t} / B_{0}\right)$

where $B_{0}=$ initial biomass; $B_{t}=$ final biomass

Grazed biomass $G=g \times B^{*}$;

$$
\text { thus } \% P_{\mathrm{g}}=G / P_{\mathrm{g}} \times 100=g / \mu \times 100
$$

Results and discussion. Typical profiles taken from 1 station, which were representative for all stations of each drift study, are shown in Figs. 2 \& 3. In 1991, a strong thermocline occurred at $10 \mathrm{~m}$ depth (Fig. 2a). Below $60 \mathrm{~m}$ depth, a gradual increase in salinity was recorded. Below $120 \mathrm{~m}$ depth, no oxygen could be measured and $\mathrm{H}_{2} \mathrm{~S}$ concentration increased to ca $70 \mu \mathrm{M}$.

In the upper $50 \mathrm{~m}$ of the water column nutrient concentrations were low (Fig. 2b). Ammonia and phosphate concentrations increased markedly at the oxic/ anoxic interface at $125 \mathrm{~m}$ depth (further also referred to as chemocline) whereas nitrate concentrations peaked between 80 and $100 \mathrm{~m}$ depth. Nitrite concentrations were low throughout the water column.

Pico- and nanoplankton consisted of chroococcoid cyanobacteria cf. Synechococcus, phototrophic flagellates, bacteria, heterotrophic nanoflagellates and ciliates. The increase of pico- and nanoplankton organ- 
Fig. 2. Profiles of (a) temperature, salinity, $\mathrm{O}_{2}$ and $\mathrm{H}_{2} \mathrm{~S}$ concentrations; (b) ammonia, phosphate, nitrate and nitrite concentrations; (c) abundances of Synechococcus (Syn.), photoautotrophic nanoflagellates (ANF) and bacteria (Bact.) and $\mathrm{CO}_{2}$-dark fixation; (d) abundance of ciliates. All profiles are taken from the same station and are representative of all stations of the drift study 1991

Fig. 3. Profiles of (a) temperature, salinity, $\mathrm{O}_{2}$ and $\mathrm{H}_{2} \mathrm{~S}$ concentrations; (b) ammonia, phosphate, nitrate and nitrite concentrations; (c) abundances of Synechococcus (Syn.), photoautotrophic nanoflagellates (ANF) and bacteria (Bact.); (d) abundance of heterotrophic nanoflagellates (HNF). All profiles are taken from the same station and are representative of all stations of the drift study 1992

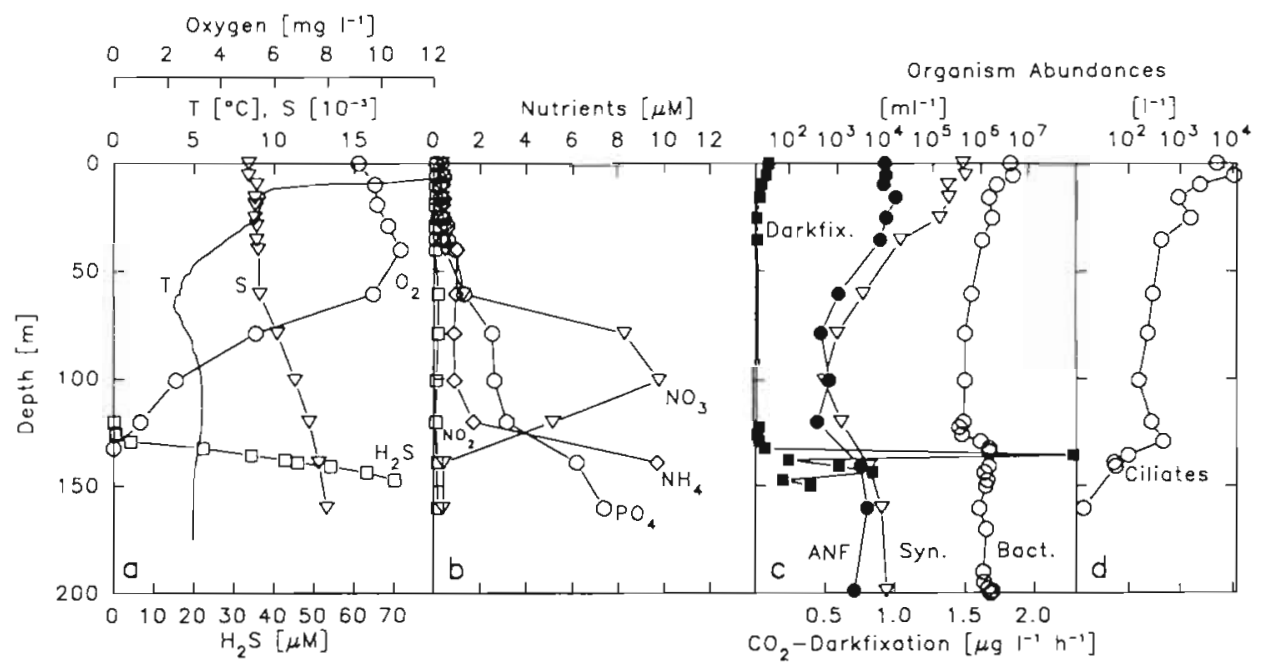

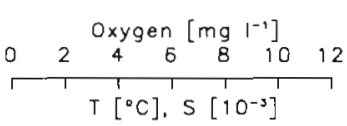

Nutrients $[\mu \mathrm{M}]$

Organism Abundonces $\left[\mathrm{ml}^{-1}\right]$

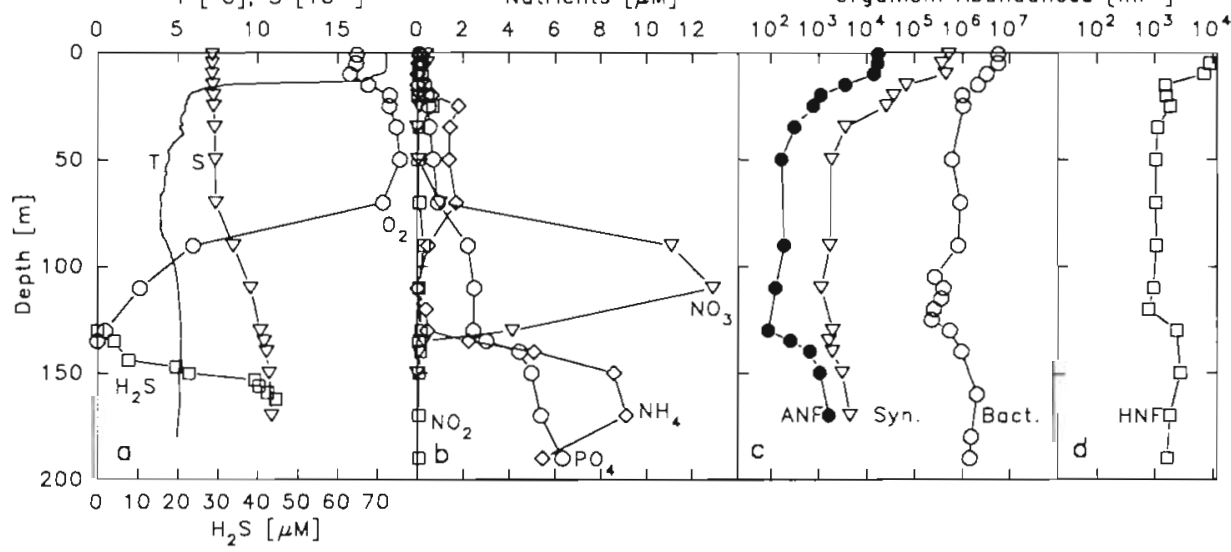

isms below $120 \mathrm{~m}$ depth was spatially related to the oxic/anoxic interface (Fig. 2c). Between 100 and $160 \mathrm{~m}$ depth, abundance of chroococcoid cyanobacteria increased from 1000 to $8000-10000$ cells $\mathrm{ml}^{-1}$, corresponding to 1 to $2 \%$ of surface values. For phototrophic nanoflagellates, a similar increase from 500 to $3000-4000$ cells $\mathrm{ml}^{-1}$ was obvious, amounting to $50 \%$ of values in upper layers. Bacterial numbers increased from $0.3 \times 10^{6}$ to $1.3 \times 10^{6}$ cells $\mathrm{ml}^{-1}$, corresponding to 30 to $50 \%$ of surface values. Below the chemocline, a shift in size structure was observed in favour of larger bacteria. Abundances of heterotrophic nanoflagellates amounted to 10 to $37 \%$ of surface values (Trenkel 1992; data not shown). Ciliate abundance (Fig. 2d) increased from 160 to 480 cells l$^{-1}$, amounting to $10 \%$ of surface values. Below $120 \mathrm{~m}$ depth, ciliate population structure completely differed from those in overlaying layers. As many as 18 to 20 species occurred in surface waters but only 4 to 5 different species were found at the oxic/anoxic interface, among them specimens of the genus Metopus.
$\mathrm{CO}_{2}$-dark fixation (Fig. 2C) peaked sharply at the chemocline $\left(2.2 \mu \mathrm{g} \mathrm{C} \mathrm{l}^{-1} \mathrm{~h}^{-1}\right)$. This corresponded to an average of $30 \%$ of surface primary production. Values of $\mathrm{CO}_{2}$-dark fixation below the chemocline were $700 \%$ higher in anoxic than in oxic waters.

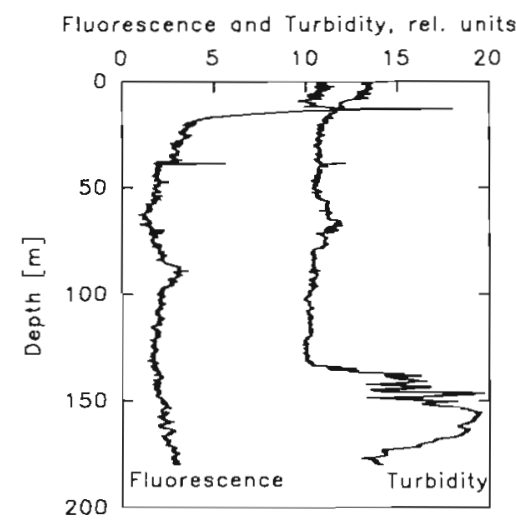

Fig. 4. Profiles of fluorescence and turbidity during cruise BAMBI '92. One profile which is representative for each station of the drift study 1992 is shown 
Table 1. Primary production potential normalized to cell numbers of phototrophic picoplankton of samples from nearsurface and anoxic depths under oxic and anoxic conditions. nd: not detectable

\begin{tabular}{|lcc|}
\hline Depth (m) & Condition & $\begin{array}{c}\text { Cellular primary } \\
\text { production } \\
\text { (fg } \mathrm{C} \mathrm{h}^{-1} \mathrm{cell}^{-1} \text { ) }\end{array}$ \\
\hline BAMBI '91 (incubated at 20 ${ }^{\circ} \mathrm{C}$ ) & \\
5 & Oxic & 4.9 \\
160 & Oxic & 39.5 \\
160 & Anoxic & nd \\
& & \\
BAMBI '92 (incubated at $18^{\circ} \mathrm{C}$ ) & 8.2 \\
1 & Oxic & 24.5 \\
170 & Oxic & nd \\
170 & Anoxic & \\
\hline
\end{tabular}

Hydrographic conditions during BAMBI '92 (Fig. 3a) were fairly similar to those in 1991. The chemocline was encountered at $135 \mathrm{~m}$ depth. The vertical distribution of nutrients (Fig. 3b) was comparable to that in 1991, as well. In situ fluorescence as an indicator of phototrophic biomass showed a slight increase in anoxic waters and turbidity peaked between 135 and $175 \mathrm{~m}$ depth (Fig. 4).

Typical profiles of abundances of Synechococcus, phototrophic nanoflagellates and bacteria (Fig. 3c) displayed both similar shapes and cell numbers as compared to the 1991 study. The increase of cell numbers in aphotic depths again coincided with the oxic/anoxic interface. Cell abundances in anoxic waters amounted to $1 \%$ of surface values for Synechococcus, $10 \%$ for phototrophic nanoflagellates, and $50 \%$ for bacteria, thus comparable to the 1991 results. Abundance of heterotrophic flagellates increased within the chemocline, concentrations rose from 780 to 2400 cells $\mathrm{ml}^{-1}$, amounting to $23 \%$ of surface values. No data for abun-

Table 2 . Growth and grazing rates as estimated by the serial dilution technique. Representative data from 1 out of $4(2 \mathrm{~m}), 1$ out of $1(160 \mathrm{~m})$ and 1 out of $2(170 \mathrm{~m})$ experiments

\begin{tabular}{|lccc|}
\hline Organism group & $\begin{array}{c}\text { Growth rate, } \mu \\
\left(\mathrm{d}^{-1}\right)\end{array}$ & $\begin{array}{c}\text { Grazing rate, } g \\
\left(\mathrm{~d}^{-1}\right)\end{array}$ & $\begin{array}{c}\% \text { Gross production } \\
\text { grazed, } \% P_{\mathrm{g}}\end{array}$ \\
\hline $\begin{array}{l}\text { BAMBI '91 (2 m) } \\
\text { Bacteria }\end{array}$ & 0.26 & 0.30 & 115 \\
Cyanobacteria & 0.88 & 0.72 & 82 \\
BAMBI'91 (160 m) & & & \\
Bacteria & 0.36 & 0.65 & 181 \\
Cyanobacteria & 0.85 & 1.29 & 152 \\
BAMBI '92 (170 m) & & & 48 \\
Bacteria & 0.86 & 0.41 & 89 \\
Cyanobacteria & 1.33 & 1.19 & \\
\hline
\end{tabular}

dance of ciliates and $\mathrm{CO}_{2}$-dark fixation are available for the 1992 study.

Primary productivity of phototrophic picoplankton was not detectable under anoxic conditions in both studies whereas reoxygenation of deep-water samples resulted in measurable activities (Table 1). Cellular primary production in reoxygenated deep water was higher than in oxic surface water. Keeping in mind that all experiments were conducted at similar temperature and light regimes, high cellular primary production of the deep-water samples was enhanced by the rise in temperature during incubation. Also higher phosphate and ammonia concentrations in the deep-water samples (Figs. 2b \& 3b) might have stimulated primary production. These experiments proved that cells are still viable under anoxic conditions. The presence of $\mathrm{H}_{2} \mathrm{~S}$ seems to have inhibited biochemical pathways involved in photosynthesis. This inhibition was reversible by reoxygenation. Furthermore, it was possible to cultivate cells of the genus Synechococcus from deepwater samples under surface conditions in glass bottles (J. de Wall, Institut für Meereskunde, Kiel, pers. comm.).

Serial dilution experiments in 1991 showed considerable grazing rates on chroococcoid cyanobacteria and bacteria in anoxic waters, grazing rates being higher than growth rates (Table 2). Growth rates compared well to surface values but grazing rates were about $50 \%$ higher in anoxic waters. Since no precautions were taken, contamination with oxygen may have enhanced growth and grazing rates of facultative anaerobic organisms. Therefore, strictly anoxic grazing experiments were performed in 1992, revealing again considerable grazing impact on cyanobacteria and heterotrophic bacteria. Nonetheless, unlike 1991, growth rates were higher than grazing rates. The results of both cruises point towards high growth rates of Synechococcus in aphotic anoxic depths, comparable to those in surface layers.

The unexpected increase in abundance of heterotrophic and especially phototrophic organisms of the microbial food web within or below the chemocline raises the questions as to whether this increase is due to vertical transport of these cells and subsequent passive accumulation in the absence of grazers or due to in situ reproduction of these organisms.

Considering Stoke's Law, cells of the picoplankton size fraction have neglectable sinking rates (Fournier 1971, Platt et al. 1983, Bienfang 1985). From this, Fournier (1971) inferred that cell aggregates formed in upper layers are able to sink to the deep sea and Lochte \& Turley (1988) 
reported that cyanobacteria and bacteria in Atlantic mid-waters sedimented as phytodetritus to greater depths. Silver et al. (1986) mentioned cells associated with 'rapidly sinking detritus'; from these organic particles, cells are delivered very rapidly to a 'pool of suspended cells' at greater depths. Another device of vertical transport of cells are fecal pellets, containing highly pigmented cyanobacteria and phototrophic cells (Silver \& Alldredge 1981). In the 1991 study, aggregates were found in a sediment trap located in $200 \mathrm{~m}$ depth containing phototrophic nanoflagellates but no Synechococcus and only very few fecal pellets were observed (A. Stuhr, Institut für Meereskunde, Kiel, pers. comm.). These findings suggest a possible

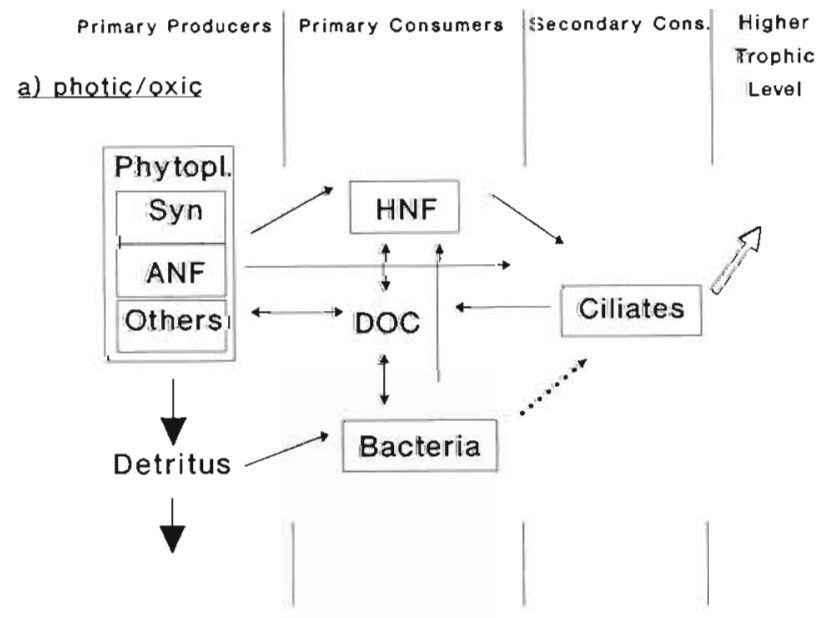

b) aphotic/anoxic

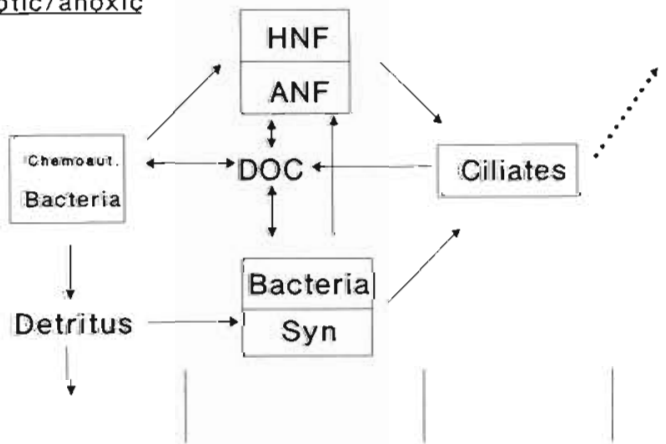

Fig. 5. Schematic model of the microbial food web in (a) photic/oxic and (b) aphotic/anoxic waters of the central Baltic Sea. Boxes on the left represent primary producers, boxes in the middle primary consumers of particulate and dissolved organic matter, respectively, and boxes on the right stand for secondary consumers. In the case of one-sided arrows, arrow heads point at grazers (except the connection between ciliates and DOC). For DOC, arrows show uptake and release of dissolved organic matter. Dotted arrows point out subordinate relations. For detritus and transport of organic matter to higher trophic levels, thickness of arrows indicates different amounts, which are representatitve for the whole food web. Syn: Synechococcus, ANF: photoautotrophic nanoflagellates (mixo-/phagotroph); HNF: heterotrophic nanoflagellates;

DOC: dissolved organic carbon; Phytopl.: phytoplankton vertical transport of aggregated pico- and nanoplankton to greater depths which nonetheless might have been too small to account for the increase below the chemocline. Under the epifluorescence microscope only unicellular autotrophic cells were observed at greater depths. A resuspension of aggregated cells could explain the occurrence of only unicellular cells at greater depths and the absence of Synechococcus in the aggregates observed in the sediment traps. However, it might have been also a combination of events, and a flux of aggregates prior to our investigation cannot be excluded.

Although Silver et al. (1986) calculated life expectancies of several weeks to years for cyanobacteria and eucaryotic nanoplankton in the deep sea, it still remains unclear how these originally oxyphototrophic organisms are maintaining survival and even growth under such uncomfortable conditions. The results of the serial dilution experiments pointed out that all organisms of the picoplankton size fraction were able to grow. The primary production experiments implied that cyanobacteria are not killed in the presence of $\mathrm{H}_{2} \mathrm{~S}$ but remain viable. The observed growth rates under anoxic conditions might result from heterotrophic activity. Heterotrophy is evidenced for at least some Synechococcus strains (Waterbury et al. 1986, Paerl 1991). In the case of phytoflagellates, heterotrophy (phagotrophy) is stated by Bird \& Kalff (1989) and Antia et al. (1991), whereby these findings are restricted to oxic conditions so far. Nonetheless, there is no evidence that heterotrophy/mixotrophy of phytoplankton is impossible under anoxic conditions. Bacterial growth rates in anoxic depths were about 3 times higher than in surface layers. Chemoautotrophic and heterotrophic growth could not be distinguished for bacteria. $\mathrm{CO}_{2}$-dark fixation values indicate that an important amount of the overall bacterial growth is attributed to chemoautotrophic bacteria. However, facultative and obligate anaerobic heterotrophic bacteria were also observed in anoxic depths in the Gotland Sea (Gast \& Gocke 1988).

Setälä (1991) observed similar ciliate species within and below the chemocline of the Gotland Basin. The author supposed that the increasing size of bacteria in these depths seem to favour growth conditions for ciliates which are able to survive high $\mathrm{H}_{2} \mathrm{~S}$ concentrations. Furthermore, chroococcoid cyanobacteria could advance a survival of ciliates under these circumstances. Kuosa (1990) demonstrated grazing of ciliates on Synechococcus in the Baltic Sea. Moreover, the change in ciliate species composition related to anoxic conditions and the occurrence of Metopus spp. give evidence that, like in oxic waters, ciliates as grazers of microbial food web organisms are active at the oxic/anoxic interface and probably below. Several spe- 
cies of the genus Metopus are able to live in anoxic environments (Fenchel \& Finlay 1990).

The presence of auto- and heterotrophic bacteria, viable cyanobacteria, flagellates and ciliates in anoxic depths of the central Baltic Sea gives evidence of an intact microbial food web. Although in both systems (photic/oxic and aphotic/anoxic) the same organism groups compose the food web, their role under oxic and anoxic conditions is different (Fig.5). Below the chemocline, photoautotrophic organisms are substituted by chemoautotrophic bacteria and possibly act as primary consumers of particulate (ANF) and dissolved (Syn) organic matter. Auto- and heterotrophic anoxic processes supply less energy than oxic processes. Therefore this system could be seen as a 'low level system', which functions properly but cannot build up as high production rates and biomasses as a photic/oxic system. For this reason, the transfer of organic matter to higher trophic levels should be low. This might explain low ciliate numbers in the anoxic microbial food web. These organisms possibly represent top predators within this system already.

The oxic/anoxic interface is an exception to the hypothesis presented here. Chemoclines in the Baltic Sea are known to be productive zones with rapid turnover of organic material, especially in the microaerobic layer (Brettar 1991, Giesenhagen \& Hoppe 1991).

Further investigations should evaluate the structure, dynamics and importance of the postulated anoxic microbial food web, its seasonal variability and the physiological response of phototrophic organisms upon anoxic conditions.

Acknowledgements. We thank the captain and crew of RV 'Alkor', as well as our colleagues Peter Fritsche, Nikolaus Gelpke, Petra Krischker and Jurgen de Wall for their assistance at sea. Also we thank Rolf Gradinger and 2 anonymous referees for helpful suggestions for the manuscript. This work was funded by Stiftung Volkswagenwerk grant Le-l/63699 and DFG Ho 715/3-3.

\section{LITERATURE CITED}

Antia, N. J., Harrison, P. J., Oliveira, L. (1991). The role of organic nitrogen in phytoplankton nutrition, cell biology and ecology. Phycologia 30: 1-89

Bienfang, P. K. (1985). Size structure and sinking rates of various microparticulate constituents in oligotrophic Hawaiian waters. Mar. Ecol. Prog. Ser. 23: 143-151

Bird, D. F., Kalff, J (1989). Phagotrophic sustenance of a metalimnetic phytoplankton peak. Limnol. Oceanogr 34(1): $155-162$

Brettar, I. (1991). Denitrification in the water column of the central Baltic Sea. Regulatory factors and microbiological aspects. Ber. Inst. Meereskd. Univ. Kiel 208: 1-145
Davis, P. G., Caron, D. A., Johnson, P. W., Sieburth, J. McN (1985). Phototrophic and apochlorotic components of picoplankton and nanoplankton in the North Atlantic: geographic, vertical, seasonal and diel distributions. Mar. Ecol. Prog. Ser. 21: 15-26

Fenchel, T., Finlay, B. J. (1990). Oxygen toxicity, respiration and behavioural responses to oxygen in free-living anaerobic ciliates. J. gen. Microbiol. 136: 1953-1959

Fenchel, T., Kristensen, L. D., Rasmussen, L. (1990). Water column anoxia: vertical zonation of planktonic protozoa. Mar. Ecol. Prog. Ser. 62: 1-10

Fournier, R. O. (1970). Studies on pigmented microorganisms from aphotic marine environments. Limnol. Oceanogr. 15: $675-682$

Fournier, R. O. (1971). Studies on pigmented microorganisms from aphotic marine environments. II. North Atlantic distribution. Limnol. Oceanogr. 16: 952-951

Gast, V., Gocke, K. (1988). Vertical distribution of number, biomass and size-class spectrum of bacteria in relation to oxic/anoxic conditions in the Central Baltic Sea. Mar. Ecol. Prog. Ser. 45: 179-186

Giesenhagen, H. C., Hoppe, H. G. (1991). Seasonal variations in bacterial activity in the near-bottom water layer of Kie Bight (Western Baltic Sea). Kieler Meeresforsch., Sonderh 8: $14-19$

Grasshoff, K., Erhardt, M., Kremling, K. (1983). Methods in seawater analysis, 2nd edn. Verlag Chemie. Weinheim

Haas, L. W. (1982). Improved epifluorescence microscopy for observing planktonic microorganisms. Annls Inst. océanogr., Paris 58 (S): 261-266

Hamilton, R. D., Holm-Hansen, O., Strickland, J. D. H. (1968) Notes on the occurrences of living microscopic organisms in deep water. Deep Sea Res. 15: 651-656

Kuosa, H. (1990). Protozoan grazing on pico- and nanophytoplankton in the northern Baltic Sea: direct evidence from epifluorescence microscopy. Arch. Hydrobiol. 119 . $257-265$

Landry, M. R. Hasset, R. P. (1982). Estimating the grazing impact of marine micro-zooplankton. Mar. Biol. 67 : $283-288$

Lochte, K., Turley, C. M. (1988). Bacteria and cyanobacteria associated with phytodetritus in the deep sea. Nature 33 : $67-69$

Matthäus, W. (1986). Charakteristische Eigenschaften von Stagnationsperioden im Tiefenwasser der Ostsee. Beitr. Meereskde 55: 39-53

Montagnes, D. J. S., Lynn, D. H. (1987). A quantitative protargol stain (QPS) for ciliates: methods description and test of its quantitative nature. Mar. microb. Fd Webs 2: 83-93

Paerl, H. W. (1991). Ecophysiological and trophic impiications of light-stimulated amino acid utilization in marine picoplankton. Appl. environ. Microbiol. Ecol. 57: $473-479$

Platt, T., Subba Rao, D. V., Smith, J. C., Li, W. K. W., Irwin, B., Horne, E. P. W., Sameoto, D. D. (1983). Photosynthetically competent phytoplankton from the aphotic zone of the deep ocean. Mar. Ecol. Prog. Ser. 10: 105-110

Porter, K. G., Feig, Y S. (1980). The use of DAPI for identifying and counting aquatic microflora. Limnol. Oceanogr. 25: $105-110$

Setälä, O. (1991). Ciliates in the anoxic deep water layer of the Baltic. Arch. Hydrobiol. 122: 483-492

Silver, W. M., Alldredge, A. L. (1981). Bathypelagic marine snow: deep-sea algal and detrital community. J. mar. Res. 39: $501-530$

Silver, W. M., Gowing, M. M., Davoll, P. J. (1986). The 
association of photosynthetic picoplankton and ultraplankton with pelagic detritus through the water column (0-2000 m). In: Platt, T., Li, W. K. W. (eds.) Photosynthetic picoplankton. Can. Bull. Fish. Aquat. Sci. 214: $311-341$

Steeman Nielsen, E. (1952). The use of radioactive carbon $\left(\mathrm{C}^{14}\right)$ for measuring organic production in the sea. J. Cons. int. Explor. Mer 18: 117-140

Süßmuth, R., Eberspächer, J., Haag, R., Springer, W. (1987) Biochemisch-mikrobiologisches Praktikum. Thieme Verlag, Stuttgart

Trenkel, V. (1992). Untersuchungen zu trophischen Beziehungen der Organismen im 'Microbial Loop'. Diploma Thesis, Kiel University

Turley, C. M., Hughes, D. J. (1992). Effects of storage on direct estimates of bacterial numbers of preserved seawater samples. Deep Sea Res. 39: 375-394

Venrick, E. L. (1978). How many cells to count? In: Sournia, A. (ed.) Phytoplankton manual. Monogr. oceanogr. Methodol. 6: 167-180

Waterbury, J. B., Watson, S. W., Valois, F. W., Franks, D. G. (1986). Biological and ecological characterization of the marine unicellular cyanobacterium Synechococcus. In: Platt, T., Li, W. K. W. (eds.) Photosynthetic picoplankton. Can. Bull. Fish. Aquat. Sci. 214: 71-120

Zimmermann, R. (1977). Estimation of bacterial numbers and biomass by epifluorescence microscopy and scanning electron microscopy. In: Reinheimer, G. (ed.) Microbial ecology of a brackish water environment. Ecological studies 25. Springer Verlag, Berlin, p. 103-120

Manuscript first received: September 28, 1992 Revised version accepted: April 23, 1993 